\title{
The Analysis and the Application of Enterprise Resource Planning in Church Organizations
}

\author{
Astrid Lestari Tungadi and Elisabeth \\ Department of Information Technology, Atma Jaya University of Makassar, Makassar, Indonesia \\ astrid_tungadi@lecturer.uajm.ac.id
}

\begin{abstract}
The application of information technology has been widely used in both profit and non-profit oriented organizations such as in churches. Gereja Katolik Santa Perawan Maria Diangkat ke Surga (GKSPMDkS) is one of the Catholic Churches in the city of Makassar. Most of the things done by the church for the community are still manually executed, these include: data collection, requests for certificates and other services and because of this, these activities are slow and unorganized. The human resources personnel of the church are very few compared to the number of people they serve in the community. And so, getting current information on church services and programs, most times does not go down well between the Parish Pastor and members of the Pastoral Council and due to this and so, the use of information technology is needed to help the service process. And one of such technology is the Enterprise Resource Planning (ERP). The ERP is a way managing company resources using information technology. And implementing it in GKSPMDkS is expected to improve the service delivery and help to integrate communication between the community and the church. The components in the ERP system in the GKSPMDkS are financial inventory, community service, service process, HR management information distribution and sales of spiritual objects. All these components work together to improve the effectiveness of services through the use of the ICT. The results of the TELOS analysis indicated that the ERP system is workable and feasible in GKSPMDkS but requires a serious IT strategic planning as its basis of implementation.
\end{abstract}

Key words: Non-profit organizations, enterprise resource planning, church services, information technology, community, implementation

\section{INTRODUCTION}

Information technology has a great impact on human life and its use is currently progressing. According to Prabowo and Saintika (2018), adopting information technology can help universities in improving the effectiveness and efficiency of business processes (Prabowo and Saintika, 2018). It has also been widely used in profit organizations and even in some non-profit organizations like churches (Andryanto, 2014).

Gereja Katolik Santa Perawan Maria Diangkat ke Surga (GKSPMDkS) is one of the Catholic Churches in the city of Makassar. Most of the things done by the church for the community are still manually executed, like data collection issuance of certificates and so on and so, the activities are slow and unorganized. The human resources personnel owned by the church are very few compared to the number of people served in the community which was about 1500 . The church has just one parish priest and a secretariat staff and this has made serving the whole community to be difficult for the HR especially in the area of passing out information.
The church has several sections in the Pastoral Council that help in serving the community but most of them have other things they do and are therefore not doing much in terms of serving the community. The pastoral council members involve in the decision-making activities of the church still require the approval of the Parish Priest. This can lead to a miscommunication between the Parish priest, members of the Pastoral Council and the community as a whole. And because of this information technology is needed to help in the service process and one of such technology is Enterprise Resource Planning (ERP).

The ERP systems are software that integrates, manages, supervises and automates most business organization processes. And according to Ruhi and Ghatrenabi (2015), these systems are typically transaction-oriented data sharing and apply standard business rules in various functional including manufacturing, accounting, finance, marketing, sales, human resources and logistics. It is a way of managing the company's resources using information technology (Ruhi and Ghatrenabi, 2015). Yasin (2013), reported that

Corresponding Author: Astrid Lestari Tungadi, Department of Information Technology, Atma Jaya University of Makassar, Makassar, Indonesia, astrid_tungadi@lecturer.uajm.ac.id 
ERP is equipped with hardware and software to coordinate and integrate information in the business process thereby providing rapid financial analysis and reports, timely sales and production reports and in general decision making process.

The main purpose of adopting ERP system is to help in integrating various information in different departments of an organization. And its software covers areas like finance, sales, customer service and human resource management. Bajahzar et al. (2012), reported that this can be applied in various sectors such as finance, telecommunications, hotels, tourism and education.

Currently, there are a lot of research on ERP systems in profit-oriented business organizations that are into productions (Emita and Kusuma, 2008; David et al., 2013; Zornada and Velkavrh, 2005). And according to Andryanto (2014), Gundogar and Sunter (2010), it can also, applied in non-profit oriented business organizations. Also, Ernita and Kusuma (2008) developed an e-Commerce that adapts to the ERP concept in retail companies. The system developed in this research is useful for retail companies in managing information.

David et al. (2013) also, conducted analysis and systems in Small and Medium Enterprises (SMEs). The study only focused on the sales department and the ERP system design was in the form of use case diagrams, class diagrams, entity relationship diagrams and architectural deployment diagrams which aimed to make the running of SMEs to be more efficiently. Data processing and information integration in the system design includes master data, pre-sales activities (inquiry and quotation), sales activities (sales orders) to data and payment information (David et al., 2013).

In another study, Zornada and Velkavrh (2005) made a comparison of the ERP application among universities in Slovenia. It was discovered that ERP had covered most activities in the universities, such as business activities, education, research, human resources, administrative support for the educational process and administrative support for research process. This is an indication that ERP systems can be applied in organizations managing services and it covers most of the universitie's activities (Zornada and Velkavrh, 2005).

Also Andryanto (2014) studied the implementation of the feasibility of Adempiere ERP applications in supporting church administration systems. The results of the study indicated that the Adempiere ERP application was workable for as it has a huge impact on the data processing. It was much easier and efficient compared to manual systems. This also allowed the integration of information between the church administration and other assemblies (Andryanto, 2014).

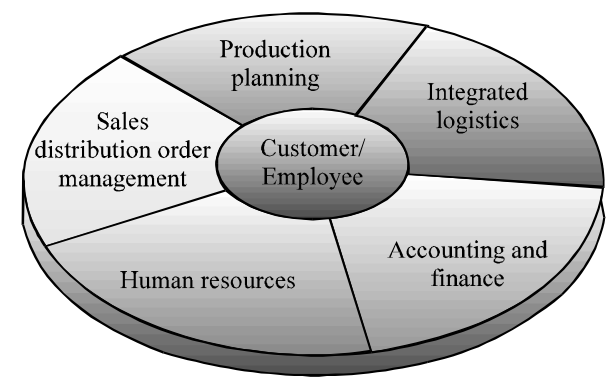

Fig. 1: Main components of ERP (O'Brien and Marakas, 2010)

Gundogar and Sunter (2010) in a study, examined the implementation of ERP system in a foundation in Turkey. With the use of this system, proper analysis could be carried out on the business transactions of the foundation (Gundogar and Sunter, 2010).

Furthermore, Riess (2012) researched on the the fact that ERP can also adjust to meet the unique needs of non-profit oriented business organizations (Riess, 2012). And GKSPMDkS is an example of such business organization. The existence of an ERP system in the church is expected to increase the effectiveness of services and integrate communication between the community and the church, comprising of the Pastor, Secretariat and Pastoral Council. In that study, an analysis of ERP implementation was conducted to obtain ERP system components in the GKSPMDkS using TELOS analysis with the aim of determining the feasibility of implementing it. It was concluded that ERP system helped the service delivery and gave a well-improved organization.

Enterprise resource planning: Enterprise Resource Planning (ERP) is a corporate system that includes all functions contained within a company that are supported by several integrated software modules for the company's internal business processes. For example, ERP Software for manufacturing companies generally, starts from processing incoming data, tracking the status of sales inventory, shipping and collecting goods and estimating raw materials and human resource requirements $\left(O^{\prime} B\right.$ Brien and Marakas, 2010). And as shown in Fig. 1, there are 5 main components of the ERP system.

The ERP is a cross-functional or information system that can be applied in manufacturing and service companies such as factories, logistics, distribution, accounting, finance and human resources to integrate and automate processes. It is an investment and also, the backbone of the company in improving its performance, efficiency and business developments. In principle with the ERP system, an industry runs optimally and reduces 


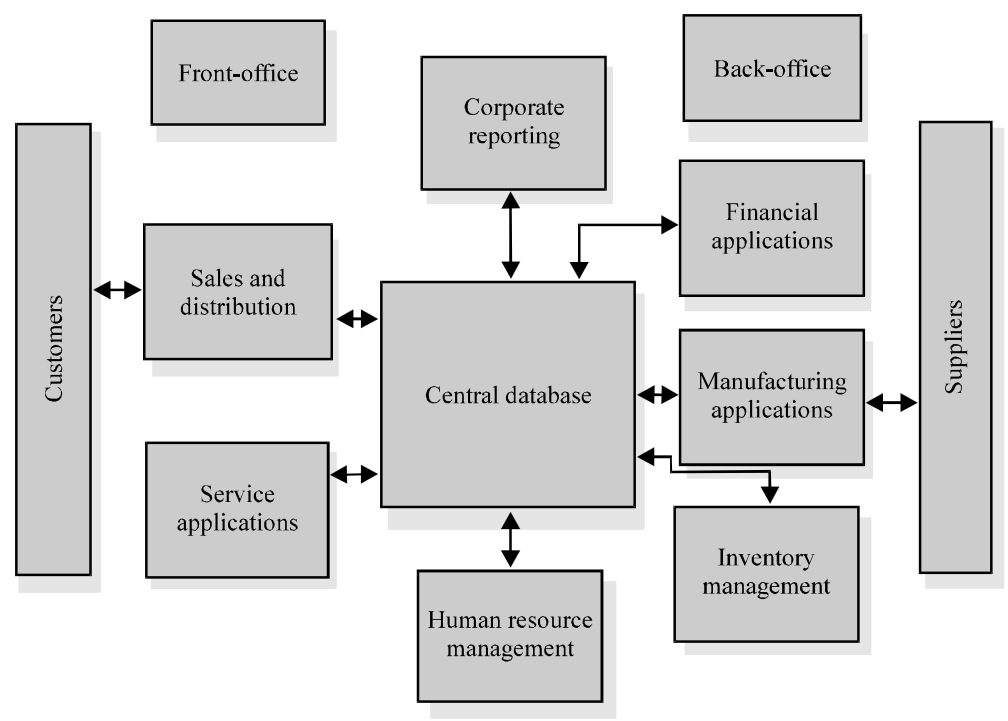

Fig. 2: Basic concepts of ERP (Rashid et al., 2012)]

inefficient operational costs such as inventory costs and costs of losses due to technical errors (Yasin, 2013). And according to Dhewanto and Falahah (2007), it can eliminate the gap between departments and functionalities of business processes information systems and resources. Its systems record the flow of business resources (such as money, raw materials and production capacity) and the status of agreements made in business processes (such as customer orders, purchase orders and employee salaries) in all the departments that enter data into the system (Rashid et al., 2012). The main concept of ERP can be illustrated in Fig. 2.

\section{MATERIALS AND METHODS}

This research uses a structured design that has several stages as shown in Fig. 3. The data collection uses the observation method interviews with Parish Priests, Secretariat staff and by also distributing questionnaires to 100 respondents. These were processed and analyzed so as to explain the business processes and the effectiveness of parish services currently, taking place in the Gereja Katolik Santa Perawan Maria Diangkat ke Surga. Then a feasibility study was conducted on the ERP, so as to identify and determine whether the design can be done or not. This study uses the Engineering, Economics, Legal, Operations and Schedule (TELOS) factor in doing it.

The effectiveness analysis of church service: In order to find out the effectiveness of parish services in the GKSPMDkS, an interview was conducted with the Parish

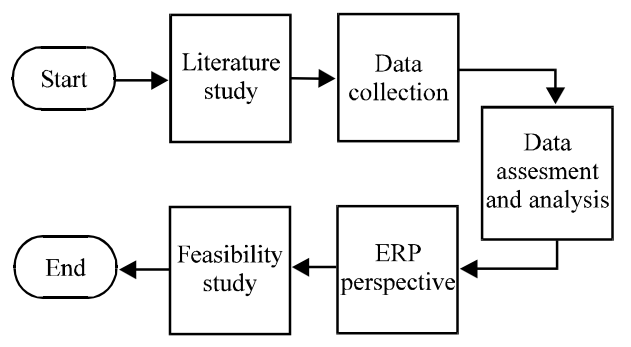

Fig. 3: Research methodology

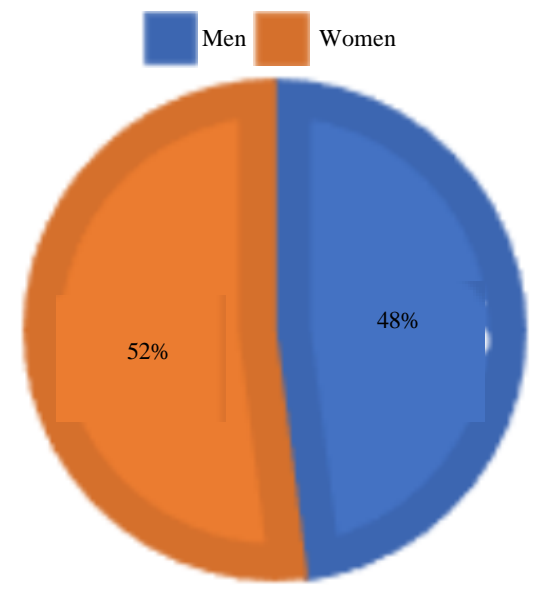

Fig. 4: The participants profile of questionnaire

Pastor and the Church Secretariat. But to know the weaknesses of the services, 100 members of the community were interviewed with questionnaires. The profile of the community involved in the questionnaire can be seen in Fig. 4. 
The following conclusions were drawn based on the observations, questionnaires and interviews relating to the effectiveness of community services. The current mode of distributing information from the church to the community has not been fully maximized, since, information distribution is more dominant in the church environment such as announcements, news and bulletin boards. The registration and arrangement of the sacrament was not effective because the community data is recorded manually, so, it makes the verification a very long process thereby wasting time. The process of purchasing goods currently has no problems because it is quite easy and fast.

Business process analysis: Business process analysis is carried out to determine the current status of GKSPMDkS in that regard. This analysis is carried out by reviewing each ERP component including financial, community service inventory, human resources, distribution and other services rendered to the community.

Financial business process: Financial data collection uses a simple Microsoft Excel. The financial data for each year is recorded per file and per sheet for the monthly transactions. The format used was recording the debit portion for the income of the fund and the credit portion for the expenditure. The Church Secretariat staff was responsible for inputting the church's financial data under the supervision of the parish priest. They sale some spiritual items, so as to get additional money for funding the church and this was handled by the church sexton. The proceeds of the sales are recorded and the profit sharing is carried out with those who sell the items.

Business process inventory: The section that responsible for inventory in the GKSPMDK is the Pastoral Council equipment section. This study is responsible for checking and repairing the infrastructure owned by the church in case there is any damage. Such repair expenses are recorded in the church funding file. Those facilities that have been damaged and cannot be repaired are replaced through donors or by purchasing new ones through the church funds.

Community service business process: Services within the community are generally conducted by the Parish Priest and the Chaplain Priest when requested. And such request is made by the regional head or by the people. In providing worship services in the church, the parish priest was assisted by several pastors from the St. Peter Claver Seminary. The service request process is carried out directly by the Church Secretariat staff or Parish Priest. In
Table 1: Amount of HR in GKSPMDkS

\begin{tabular}{lll}
\hline HR staff & Status & Amount \\
\hline Secretariat staff & Permanent & 1 person \\
Church sexton & Permanent & 2 persons \\
Security staff & Outsourcing & 4 persons \\
Cleaning staff & Outsourcing & 3 persons \\
\hline
\end{tabular}

providing worship services at their homes, the Parish Priest makes notes on the schedule board as a reminder for each month. The timetable is also used to record other activities such as meetings, recollections and other service-related activities.

Other community services involving the scheduling of mass officers such as acolytes, conductors organists, lectors and pro deacons were also assessed and most of it are still done manually. The Chairperson of the Liturgical Section of the pastoral council is tasked with determining the schedule of mass officers. One obstacle often encountered is the difficulty in finding a replacement when the appointed officer is suddenly absent and does not report.

HR management business process: The $H R$ management process in GKSPMDkS is still done in the conventional way because the number of personnel involved are very few. Payments are made every month to the Church Secretariat staff such as church funds, human resources, security officers and cleaning staff that are outsourced. Table 1 shows the amount of HR involved in business processes in the GKSPMDkS.

Distribution business process: The process of distributing information related to the church and the needs of the community is currently carried out using several media information tools which are mainly offline and online. Offline tools of information media involve church bulletin boards, banners, church weekly newsletters and announcements before worship is held. Then for the online information media, the church has a website https://gerejamamajang.wordpress.com. But the website does not always updated, so, people do not get current information online.

Business process services for people: The community service that is often carried out is the giving of sacraments to the people. And to be a part of this, the members of the community need to register. Currently, the church make use of a form that must be completed with several supporting documents. In addition, the Regional Chairperson has the role of assisting the community in verifying the sacrament registration forms. 


\section{RESULTS AND DISCUSSION}

ERP perspective on church organizations: The results show that the ERP components applied in GKSPMDkS were seven and these components are shown in Fig. 5.

Financial system components: The financial system component deals with the accounting information system which functions in recording the entire flow of funds by the church. In addition, reports on the income and use of funds owned by the church become accountable and transparent. The results of the report recapitulation of income and use of funds are displayed as information on the website to be easily accessed by the people.

Component of the inventory system: The inventory system component records the status of other systems, like the financial and community services. Apart from being a module for recording the entire inventory owned by the church, this component can also show the economic value of all the inventory owned. It also, records inventory usage, such as chairs and tables and help as decision maker in providing the parish with other inventory.

Service system components for the community: The service system is one of the most important components of ERP. It handles the data collection for the whole community. And the collection of these data are also used while registering for sacrament. More so, this can also help the parish priest in analyzing the distribution of people in different regions in terms of income and age, so that, assistance can be spread. People can also use this component to register if they need services at home.

Components of the community service system: The community service system component has several

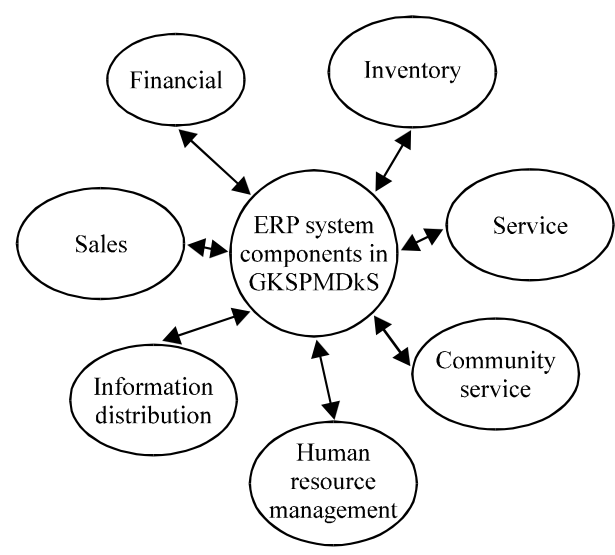

Fig. 5: ERP system components in GKSPMDkS modules, such as staff scheduling arrangements, access to St. Peter's Claver Seminary and schedule of activities. The officer scheduling module in the form of a task schedule and confirmation of the officer willingness, if he is unable to work on the schedule produced. In addition, access to the seminary to provide information on the needs of the Pastor who can assist in delivering services and giving confirmation of the Father's willingness. The other module is a reminder for the Parish Priest to the service schedule that should be performed.

The parish service is generally carried out by Parish Priest and Chaplain Priest by following the ministry's request in church or at home. The process of requesting for service by the community members can be through the regional head or the people themselves. In providing worship services in the church, the parish priest was assisted by several pastors from the St. Peter Claver Seminary as worship leaders. Then the service request process is carried out directly by the Church Secretariat staff or Parish Priest.

HR management system components: The HR system component has an HR management information system which functions in recording all $\mathrm{HR}$ owned and their respective information. Details like length of work, salary and so on are recorded here.

Information distribution system component: The component of the information distribution system is a website independently hosted, so that, all components of the ERP system can be integrated to it. In addition, it can also be in the form of sending SMS to the Regional Chairperson or the organizing committee for activities in the church or any meeting.

Sales system components: The sales system component is for recording the proceeds of the spiritual items sold. This is related to the financial records and it also give the information about the benefits of those spiritual items.

Feasibility study: Feasibility studies with TELOS factors are conducted to identify and determine whether the ERP system components planned are feasible to be implemented in the future. The feasibility study was conducted by interviewing the Parish Priest and Church Secretariat staff.

Technical feasibility: The use of information and communication technology has not been fully integrated into the system. The number of facilities available is also limited in serving the community with about 1500 people. This is because the entire business process is still 
Table 2: Use of ICT facilities

\begin{tabular}{ll} 
ICT facilities & Information \\
\hline Secretariat computer & 1 item \\
Mass LCD computer & 1 item \\
Printer & 2 items \\
Parish Priest laptop & 1 item \\
Internet & $10 \mathrm{Mbps}$ \\
Website & Hosting via. wordpress.com \\
\hline
\end{tabular}

conducted manually. Also, the website is not properly managed as data is not being updated. The use of ICT facilities in Table 2. With ICT facilities that are owned now gradually developed, ERP implementation is considered technically feasible.

Economic feasibility: In terms of economic feasibility, GKSPMDkS has relied on donations from the community for its daily operations. And for the use of ICT facilities, some are donations from the community while some other facilities are purchased by individuals.

Legal feasibility: From a legal overview, there is no church law or state law dishonored regarding the design of ERP. This application is expected to help in improving the service of the community continually.

Operational feasibility: The pastor and the Church Secretariat staff are qualified in terms of their operation, especially in the use of ICT facilities. They currently use computers in supporting their daily operations such as making correspondence, recording financial data and other activities.

Schedule feasibility: In designing and implementing ERP in the future, it is said to be feasible on a schedule. This is because obtaining ICT-based system requires a long time and a good strategic planning.

\section{CONCLUSION}

In conclusion, the enterprise resource planning system is workable and can be applied at the church by reviewing it from the side of non-profit organizations. Considering the results of data collected through the seven ERP system components, it is seen that the development of all these components will improve the effectiveness of their general services. The advice from this research is that there is a need for IT strategic planning as the basis for the development of an ERP system in GKSPMDkS. More so, it is necessary to implement each ERP component that has been designed, for the purpose of effectiveness in service delivery.

\section{REFERENCES}

Andryanto, A.C., 2014. [Implementation of the enterprise resource planning adempiere application to support Church administration systems (Case Study: Pentecostal Church in Indonesia Siloam Salatiga)]. Ph.D Thesis, Satya Wacana Christian University, Salatiga, Indonesia. (In Indonesian)

Bajahzar, A., A. Alqahtani and A. Baslem, 2012. Successful implementation of Enterprise Resource Planning (ERP). Proceedings of the 2012 International Conference on Advanced Computer Science Applications and Technologies (ACSAT), November 26-28, 2012, IEEE, Kuala Lumpur, Malaysia, ISBN:978-1-4673-5832-3, pp: 156-160.

David, W., Y. Ruldeviyani and P. Sandhyaduhita, 2013. Analysis and design of Enterprise Resource Planning (ERP) system for Small and Medium Enterprises (SMEs) in the sales business function area. Proceedings of the International Conference on Advanced Computer Science and Information Systems (ICACSIS), September 28-29, 2013, IEEE, New York, USA., ISBN:978-1-4799-4692-1, pp: 255260.

Dhewanto, W. and Falahah, 2007. [ERP (Enterprise Resource Planning) Aligning Information Technology with Business Strategy]. Informatika, Bandung, Indonesia, (In Indonesian).

Ernita, H. and A.W. Kusuma, 2008. [Development of Enterprise Resource Planning (ERP) for retail companies (In Indonesian)]. Nat. Sem. Inf., 2008: 149156.

Gundogar, E. and H.S. Sunter, 2010. An ERP application in a non-profit organization: Turkish red crescent society. Intl. J. Manage. Inf. Syst., 14: 87-98.

O'Brien, J.A. and G.M. Marakas, 2010. Introduction to Information Systems. 15th Edn., McGraw Hill, New York, USA., ISBN:9780070167087, Pages: 592.

Prabowo, W.A. and Y. Saintika, 2018. [Designing the IT balanced scorecard in the strategic map of higher education (Case Study: Telkom Technology Institute, Purwokerto) (In Indonesian)]. J. Res. Sci. Technol., 2: 27-36.

Rashid, M.A., L. Hossain and J.D. Patrick, 2012. The Evolution of ERP System: A Historical Perspective. IRM Press, London, UK., . 
Riess, C.J., 2012. Enterprise resource planning for not-forprofits: Aligning people, processes and technology across your organization. RSM US, Chicago, Illinois, USA. https://rsmus.com/pdf/wp_enterprise-resourceplanning-for-not-for-profits.pdf

Ruhi, U. and P. Ghatrenabi, 2015. Experiential learning spaces for enterprise resource planning courses in business schools. Proceedings of the 2015 5th International Conference on E-Learning (ECONF), October 18-20, 2015, EEE, Manama, Bahrain, pp: 316323.
Yasin, V., 2013. [The importance of Enterprise Resource Planning (ERP) systems in the framework of building resources at a company (In Idonesian)]. Inf. Manage. J., 1: 1-18.

Zornada, L. and T.B. Velkavrh, 2005. Implementing ERP systems in higher education institutions. Proceedings of the 27th International Conference on Information Technology Interfaces, June 20-23, 2005, IEEE, Cavtat, Croati, ISBN:953-7138-02-X, pp: 307-313. 